\title{
The Influence of Whole Brain Teaching (WBT) to the Motoric and Linguistic Skills of Preschoolers
}

\author{
Ahmad Zaki Emyus \\ The doctoral program of State University of Malang, Indonesia, \\ ahmadzakiemyus@ikipjember.ac.id
}

I Nyoman Sudana Degeng

State University of Malang, Indonesia, nyoman.sudana.d.fip@um.ac.id

Punaji Setyosari

State University of Malang, Indonesia, punaji.setyosari.fip@um.ac.id

\section{Saidah Ulfa}

State University of Malang, Indonesia, saida.ulfa.fip@um.ac.id

This research aims to determine the influence of the models of whole brain teaching (WBT) and visual literacy to motoric and linguistic abilities of preschool children aged 5-6 years old. The method for this research is a quasi-experiment with a non-equivalent control group design. In this research, there is one experiment class with the treatment of WBT and one control class with the treatment of a group model. The applied technique of data analysis is the Multivariate Analysis of Variance (MANOVA). This research gains some findings (1) there are influences from motoric and linguistic abilities between students using WBT and group model, (2) there is a difference of motoric and linguistic skills of children having visual literacy high and visual literacy low, (3) there is interaction between WBT and visual literacy towards children's motoric and linguistic abilities.

Keywords: whole brain teaching (WBT), visual literacy, motoric ability, linguistic ability, preschool children

\section{INTRODUCTION}

Physical ability is the individual ability to utilize one's body to solve problems, express ideas and emotions, and manipulate objects (Michelaki \& Bournelli, 2016). Based on this definition, one of the essential characteristics of the types of physical ability is the ability to use one's own body in different activities and enhance the skills for achieving one's goals. One characteristic of motoric ability (rough and soft), which is part of 
kinesthetic intelligence, is the development of the qualifications for manipulating objects (Gardner, 1993, 2011). Physical kinesthetic intelligence also involves the ability to coordinate and balance body movements, as well as strength, flexibility, speed, tactility, and haptic ability (Gardner, 2011; Hanafiah, Nurapriani, \& Gaffar, 2018; Papalia, Olds, \& Feldman, 2007).

Papalia et al., (2007) stated that the development of the language of children aged 4-6 years old has two phases as follows: (1) perceiving ability or children's ability to listen to and record voices from the languages they hear, (2) expressive ability or ability to express language and apply it for communication, e.g., to show agreement or disagreement, and for interaction. Linguistic intelligence of children aged 4-6 years old can be identified from their explicit linguistic behaviors, including: (1) enjoying interaction in a conversation, (2) telling a short or straightforward story, (3) quickly remembering names, places, dates, small details, and (4) enjoying reading books (6) spelling words, admire listening to poets, (7) enjoying language play, (8) being interested in listening to the radio, and scoring good grades in writing and reading lessons (Martini Jamaris, 2014). This day researches demonstrate more clearly how children can naturally develop writing and reading (Beaty, 1998) as well as how the children understand the world around them through exploration, and how children's brains gather information and make a set of rules from that place to help them utilize it. The research has transformed notions regarding the way's children develop and ways to support their growth (Roskos \& Christie, 2017).

Based on an observation conducted at Sinar Nyata II and III in Jember, East Java on motoric and linguistic abilities of children aged 5-6 years old, some students passively engage learning activities, there was lack of creativity in developing motoric skills and some students were not fully able to share and work together with their classmates. This problem emerged because of some obstructing factors such as teacher-dominated learning activities, learning process not based on the process of building and discovering, overly conceptual learning, not actively involving students, lack of other models the students can apply, monotonous learning, and provided activities not suitable for children's needs, leading to a small opportunity for children to explore themselves, which in turn obstruct motoric ability and minimize their chance to explore their imagination in creativity. Therefore, the implementation of the WBT model is highly required in improving children's motoric and linguistic abilities. Learning activities using the WBT model emphasizes the interaction between the teacher and the students, so learning can be enjoyable (Biffle, 2013), while the learning models applied the whole time have caused boredom to the students. Moreover, some researches explain that the WBT model can increase learning achievement (Winona \& Clark, 2016a), allowing teachers to understand how the children learn with practical ways of teaching (Jensen, 2008).

In one of the surveys conducted in California, Arizona, Texas, Montana, Louisiana, Minnesota, Missouri, Florida, Pennsylvania, Arkansas, Tennessee, and Alabama, the result was astounding. Seventy percent of instructors replied that the WBT system is 
better and more advanced than any other learning system (Biffle, 2013). The method of WBT attempts to activate the entire brain to take part in learning activities.

There is an increase in preschool institutions in East Java every year. In 2015, there were 16.724 institutions, then that number increased to 18.163 institutions in 2016, 20.154 in 2017, and 25.271 in 2018. In Jember, 2018, there are 2,201 institutions, consisting of 1,263 kindergartens, 543 study groups, 20 nurseries, dan 375 institutions similar to preschools (SPS) (Kemdikbud, 2019). The flourishing number of institutions, teachers, and students in preschool was positively appreciated to equalize education, but regarding quality, it is uncertain that there is the betterment of learning in each institution. The emergence of these issues caused the learning process not to run well as expected. Therefore, a learning model is required to solve such issues.

One of the right solutions to overcome such problems is the learning model named WBT. Aside from using the perspective of WBT, this research also implements Visual Literacy, which is thought even to influence the motoric and linguistic growth of preschoolers. Visual Literacy is the ability to learn how to interpret the vision of a message accurately and to create such a message (Pettersson, 2007). The improvement of the ability to write and read in preschoolers is made in the way of drawing. Drawing can provide ample freedom to comprehend the meaning (Davido, 1994). Children who can understand the meaning visually are categorized as having high visual literacy, while those who have difficulty understanding the meaning are classified as having low visual literacy. The rate of visual literacy of children contributes to the motoric and linguistic growth of preschoolers.

\section{THEORETICAL FRAMEWORK}

The method of WBT, previously known as "Power Teaching" is an educational reformation created in 1999 by Crafton Hills, Chris Biffle, Jay Vanderfin, dan Chris Rekstad (Wong, 2015). WBT is a model of participative learning where teachers use some techniques to involve students in learning and to make classes easy to manage in learning activities (Biffle, 2013). The core activity of WBT is how to attract an audience by involving senses, gestures, cooperation, and communication so that the audience (in this case, the students) pay more attention to the materials given by the teachers (Biffle, 2013). This learning activity emphasizes the interaction between teacher and student, for conventional learning methods still applied to this day, are proven to cause boredom to students. Other studies explain that WBT can improve learning achievements (Winona \& Clark, 2016b), allowing teachers to understand effective ways of learning (Jensen, 2008).

The advantage of the model of WBT is that it can involve all the quadrants of the brain, and to enhance a child's engagement (Biffle, 2013). WBT can be achieved by using multi-modality in a class (Calhoun, 2012). Multi-modality includes meditation, graphics, and diagrams (visual), music, discussion (oral), gesture, drama, and stories (Palasigue, 2009). WBT is learning with an instructional approach inspired by neurolinguistic imaging based on the functions of the left and right brains (Biffle, 2013). Other points regarding this approach are the engagement by activating the whole brain in learning 
(Stearns, 2017). and the principles of cooperative learning (Kirschner, Sweller, Kirschner, \& Zambrano R., 2017). Brain-based learning can also help to increase the rate of a child's recalls skill (Hajhashemi, Caltabiano, Anderson, \& Tabibzadeh, 2018; McMahon, Rose, \& Parks, 2004). For that reason, educators are required to understand relevant learning styles, as well as how the brain is functioned to create new details (Burke \& Peterson, 2007; Das, 2018).

There are six essential elements in WBT, Table 1 showing their functions to the human brain.

Table 1

Six Elements of WBT and Their Relationship with Human Brain

\begin{tabular}{|c|c|c|}
\hline Element & Part of Brain & Function \\
\hline Class-Yes & $\begin{array}{l}\text { Activating Pre-Frontal } \\
\text { Cortex }\end{array}$ & $\begin{array}{l}\text { Center of reasoning. This area resembles a switch } \\
\text { that must be turned on by repeating Class-yes for } \\
\text { other parts of the brain to process a conclusion. }\end{array}$ \\
\hline \multirow[t]{7}{*}{ Five Class Room } & Pre-Frontal Cortex, & Attention seeker \\
\hline & Broca Area & Hearing \\
\hline & Wernicke Area & Speaking \\
\hline & Visual Cortex. & Seeing \\
\hline & Motor Cortex & Hand motoric system \\
\hline & The Limbic System, & Making signals \\
\hline & Hippocampus & Long term memory \\
\hline Teach-Okay & $\begin{array}{l}\text { Same as Five Class } \\
\text { Room }\end{array}$ & $\begin{array}{l}\text { One class activity capable of involving all the } \\
\text { students in a class }\end{array}$ \\
\hline \multirow[t]{2}{*}{ Scoreboard Keys } & $\begin{array}{l}\text { Limbic System's } \\
\text { Emotions }\end{array}$ & Making signals \\
\hline & $\begin{array}{l}\text { Amygdala (Mighty Oh } \\
\text { Yeah, Mighty Groan!) }\end{array}$ & Registering pleasant and unpleasant feelings \\
\hline Hands and Eyes & Pre-Frontal Cortex & $\begin{array}{l}\text { Focusing all mental activities by viewing and } \\
\text { listening to the teacher's explanation. }\end{array}$ \\
\hline Switch & $\begin{array}{l}\text { Broca Area } \\
\text { Wernicke Area }\end{array}$ & $\begin{array}{l}\text { Allowing students to improve hearing ability } \\
\text { Allowing students to improve their speaking ability }\end{array}$ \\
\hline
\end{tabular}

There are seven techniques known as "the big seven" to implement WBT in learning; they are on table 2 : 
Table 2

The Big Seven of WBT

\begin{tabular}{|c|c|c|}
\hline \multirow{3}{*}{$\begin{array}{l}\text { Steps of WBT } \\
1 . \text { Class-Yes }\end{array}$} & \multicolumn{2}{|c|}{ Implementation in Learning Activities } \\
\hline & Teacher's Activities & Students' Activities \\
\hline & $\begin{array}{l}\text { - A teacher explains the rules and the techniques of } \\
\text { whole brain teaching. } \\
\text { - The teacher sets the class. }\end{array}$ & $\begin{array}{l}\text { - Students hear and pay attention } \\
\text { to the teacher's explanation } \\
\text { - Students follow the teacher's } \\
\text { direction } \\
\text { - Students answer Yes }\end{array}$ \\
\hline $\begin{array}{l}\text { 2. Five Class } \\
\text { Room }\end{array}$ & $\begin{array}{l}\text { The teacher explains the rules of the class, consisting of: } \\
\text { - State One, raise a finger when your name is called out, } \\
\text { and you are present } \\
\text { - } \quad \text { Rule Two, raise two fingers if you want to speak } \\
\text { - } \text { Rule Three, raise three fingers to head out of class } \\
\text { - Rule Four, if the teacher says Teach, students answer } \\
\text { Ok, then discuss with their groups. } \\
\text { - Rule Five, if the teacher says Hand and Eyes during a } \\
\text { lesson, students reply hand and eyes by closing both } \\
\text { hands and putting them on the table. }\end{array}$ & $\begin{array}{l}\text { - Students hear and pay attention } \\
\text { to the teacher's explanation } \\
\text { - Students practice rules one to } \\
\text { five }\end{array}$ \\
\hline $\begin{array}{l}\text { 3. Teach - } \\
\text { Ok }\end{array}$ & $\begin{array}{l}\text { The teacher divides students into small groups of two } \\
\text { people. } \\
\text { - The teacher orders each group to do activities such as } \\
\text { observing, writing, coloring, cutting, attaching, and } \\
\text { pay attention to the teacher's explanation. } \\
\text { - The teacher says, "Teach" to students, and students } \\
\text { teach the lessons to their teammates by using gestures. }\end{array}$ & $\begin{array}{l}\text { - Students gather in groups } \\
\text { - Students pay attention to the } \\
\text { teacher's explanation and follow } \\
\text { the teacher's instructions. } \\
\text { - Students reply "ok" and share } \\
\text { the lessons to their teammates by } \\
\text { using gesture }\end{array}$ \\
\hline $\begin{array}{l}\text { 4. The } \\
\text { Scoreb } \\
\text { oard }\end{array}$ & $\begin{array}{l}\text { - Teacher gives a satisfactory score (4 stars/smiley faces } \\
\text { "satisfactory") if students well execute the method of } \\
\text { whole brain teaching using movements/gesture } \\
\text { - Teacher gives a dissatisfactory score (4 stars/smiley } \\
\text { faces "dissatisfactory") if students do not well execute } \\
\text { the method of whole brain teaching using } \\
\text { movements/gesture }\end{array}$ & $\begin{array}{l}\text { - Students look at the scores given } \\
\text { by the teacher }\end{array}$ \\
\hline $\begin{array}{l}\text { 5. Hand and } \\
\text { Eyes }\end{array}$ & - Teacher review the results from the scoreboard & $\begin{array}{l}\text { - Students reply hand and eyes by } \\
\text { closing both hands and putting } \\
\text { them on the table. } \\
\text { - Students pay attention to the } \\
\text { teacher's explanation }\end{array}$ \\
\hline 6. Switch & $\begin{array}{l}\text { The teacher makes students pair with lower-scoring } \\
\text { classmates. } \\
\text { - Then the teacher says Switch; high scoring students } \\
\text { teach the low and middle scoring classmates. }\end{array}$ & $\begin{array}{l}\text { Students make groups } \\
\text { determined by the teacher. }\end{array}$ \\
\hline 7. Mirror & $\begin{array}{l}\text { Teacher orders students to explain the lesson using } \\
\text { gesture } \\
\text { - Students teach the lesson to low and middle scoring } \\
\text { teammates } \\
\text { - The teacher helps the student to conclude the lesson } \\
\text { using gesture }\end{array}$ & $\begin{array}{l}\text { - Students paying attention to their } \\
\text { teammates' explanation using } \\
\text { gesture } \\
\text { - Students finish the lesson using } \\
\text { gesture }\end{array}$ \\
\hline
\end{tabular}

Source: adapted from Whole Brain Teaching (Biffle, 2013)

The model of WBT provides the students with the freedom to visualize, imagine, and communicate (Wolken, 2017). This model is highly flexible and can be applied to all age groups, from preschoolers to college students (Preslee, Kharsati, \& Prakasha, 2017). WBT not only has techniques of class managing compiled in a fun way but also has the power to transform students' knowledge and characters in an entertaining way. 
The model of WBT is remarkably unique because it can be done pleasantly (Preslee et al., 2017). The strength lies in the emphasis of competence and the completion of understanding or students' ability to describe in their own words the lesson the teacher already explains (Kirschner et al., 2017). The activities created by the teachers should not be burdensome and should be relaxing for students. By involving students in the processes of fun learning activities, they will feel motivated to comprehend the lessons. Consequently, the role of the teacher in the model of WBT is to motivate students to learn and construct their knowledge through some activities, including those dealing with communication. The implementation of this model highly involves students in the steps of the learning process by understanding lesson materials through discussion and sharing the lessons by discussing. This is in line with Silver and Smith (1996) statement which describes the role of teacher as follows: (1) involving students in the steps of learning process; (2) managing students' intellectual activities through discussion and communication; and (3) helping students understand the lessons and monitoring their comprehension.

Brain-based learning is based on a theory that every brain is unique, and not all children learn in the same, and every person has their ability to learn (Duman, 2006; Tufekci \& Demirel, 2009). Brain-based learning is different from the traditional method because it stresses on meaningful learning rather than memorizing (Tufekci \& Demirel, 2009). In the steps included in the model of WBT, there are gestures often considered to be symbolic, which have positive and useful meanings to help children develop their motoric skills (rough and soft) and understand the lessons.

One of the essential physical growth during early childhood is the advanced development of the brain and nervous system (Moulson, Fox, Zeanah, \& Nelson, 2009). Although the brain keeps growing in early childhood, it does not proliferate as it did in the infant days (Santrock, 2011, 2018). When a child reaches the age of three, his or her brain has three-quarters of the size of an adult brain. At the age of 6 , his or her brain has reached $95 \%$ the size of an adult brain (Lenroot \& Giedd, 2006). WBT is based on all four quadrants of the brain (Davis, 2011; Pretorius, Steyn, \& Johnson, 2012; van Oordt, van Oordt, \& du Toit, 2014). In about $90 \%$ of the population, the left brain is responsible for logical knowledge, analysis, quantitative research, and facts, while the right brain dominantly supports intuition, emotions, spatial perception, and kinesthetic ability (Wong, 2015).

The WBT movement conducted in learning activities helps children grow their motoric muscles. Early childhood provides an ideal opportunity for children to learn how to enhance control over their muscles and movements. During this time range, nerve tracts develop (inside the brain) through the process of myelinization. This process occurs from birth until the age of 4 years old, and then it continues at a slower rate until the age of 20 years old. The process of myelinization allows children to develop control over motoric functions (Leppo, Diane, \& Crim, 2012). Therefore, it can be concluded that the model of WBT is highly influential for the motoric ability of preschoolers.

Visual literacy theory is based on conceptual components which include; visual perception, visual language, visual learning, visual thinking, and visual communication 
(Avgerinou \& Pettersson, 2011). Visual Literacy is the ability to learn how to interpret accurate visual messages and to create such messages (Heinich, Molenda, Russell, \& Smaldino, 2002). International Visual Literacy Associaton (IVLA) explains about four definitions of Visual Literacy (VL). (1) developing competence of human sight by viewing and at the same time owning and integrating other sensory experiences, (2) intelligent ability to interpret the communication of visual symbols, (3) the ability to translate visual language to verbal language and vice versa, (4) the ability to search and evaluate information in visual media (Pettersson, 2007). "Literacy" can be defined as the ability to read and write messages for three purposes: (a) recording and experiencing preservation; (b) reflecting, exploring, and widening a person's thoughts and feelings; and (c) communicating and sharing ideas with other people (Edwards \& Willis, 2000). A long history of the early studies of literacy (Wohlwend, 2009) reveals that the interaction between young children and texts, whether by using electronic screens, product packages, published books, or pencil marks on paper, involves practices consisting of semiotic, multimodal, and social practices (Burke \& Peterson, 2007; Hajhashemi et al., 2018; Michelaki \& Bournelli, 2016; Winona \& Clark, 2016b).

Elizabeth B Hurlock (1978: 159) states that motor development is defined as the development of the maturity elements of controlling body motion and brain as the center of motion. This day researches show more clearly how reading and writing can be naturally developed by children (Beaty, 1998), as well as how children perceive the world through exploration and games, and how they gather information and create a set of rules to help them make use of it. Such studies have changed the notions about how children develop and how to support their growth (Edwards \& Willis, 2000; Tufekci \& Demirel, 2009). When the researchers began to observe and report preschoolers' literacy activities, they found that the students were involved in behaviors showing the emergence of literacy, such as listening to a story, discussing and making their own story, inscribing letters, and write down their names, and making their marks. Today, there is a consensus in a society that literacy research is a process beginning from birth when infants start to experiment with oral language (Beaty, 1998). Writing and reading, along with speaking, thinking, emotional, social, and motoric skills become aspects of growth that children can master by playing with the materials in their neighborhood. However, it does not mean that the development of reading and writing skills occurs naturally without the assistance of adults (Beaty, 1998). Children require active and regular interaction using oral and written languages.

The purposes of this research are as follows: (1) determining whether there is influence of children's language and motoric skills between those who study using the model of WBT and those using group model, (2) determining whether there is a difference of motoric and language skills between children having visual literacy high (higher) and visual literacy low (lower), (3) determining whether there is an interaction between WBT and visual literacy towards children's motoric and linguistic skills. 


\section{METHOD}

\section{Research Design}

This research implements Quasi-Experimental Design with a pre-test-post-test nonequivalent control-group design with a $2 \times 2$ factorial. The conceptual relationship between variables in this study can be shown in the following Figure 1.

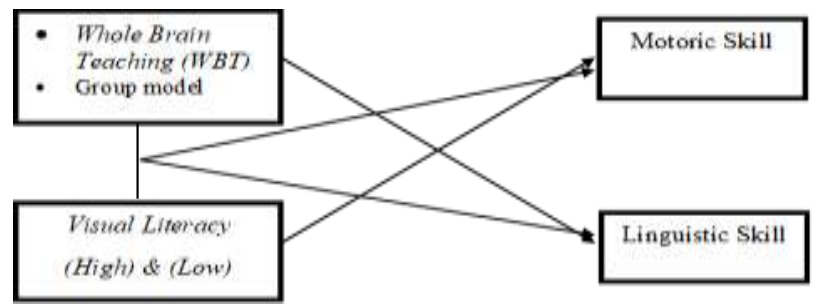

Figure 1

The Conceptual Relationship between Variables

The variables of this research comprise the independent variable, moderating variable, and dependent variable. The free variable for this research is WBT, while the moderating variable considered in this research is visual literacy (VL) classified into two types: High and Low. The bound variable observed as a consequence of free and moderating variables is preschoolers' motoric and linguistic abilities. Based on the concept of intervariable relation for this research, the quasi-experimental design will be targeted to:

Table 3

Multivariate Analysis of Variance (Manova): Two Paths

\begin{tabular}{|c|c|c|c|}
\hline \multirow{2}{*}{\multicolumn{2}{|c|}{$\begin{array}{l}\text { Free Variable } \\
\text { Moderating Variable }\end{array}$}} & \multicolumn{2}{|c|}{ Learning Model } \\
\hline & & WBT $\left(\mathrm{A}_{1}\right)$ & Group Model $\left(\mathrm{A}_{2}\right)$ \\
\hline \multirow{2}{*}{$\begin{array}{l}\text { Visual Literacy } \\
\text { (VL) }\end{array}$} & $\operatorname{High}\left(B_{1}\right)$ & $\begin{array}{l}\operatorname{VLA}_{1} B_{1} \\
\operatorname{VLA}_{1} B_{1}\end{array}$ & $\begin{array}{l}\text { VLA }_{2} B_{1} \\
\text { VLA }_{2} B_{1}\end{array}$ \\
\hline & $\operatorname{Low}\left(B_{2}\right)$ & $\begin{array}{l}\mathrm{VLA}_{1} \mathrm{~B}_{2} \\
\mathrm{VLA}_{1} \mathrm{~B}_{2}\end{array}$ & $\begin{array}{l}\mathrm{VLA}_{2} \mathrm{~B}_{2} \\
\mathrm{VLA}_{2} \mathrm{~B}_{2}\end{array}$ \\
\hline
\end{tabular}

From Table 3 , the main effect and the interaction effect of all the variables will be determined. Table 3 above shows that the preschool learning process is classified into two types of models: WBT (A1) and group model (A2). In this research, all the groups receive treatment. Visual literacy is categorized into two types: visual literacy (VL) high (B1) and visual literacy low (B2). This research will demonstrate how whole brain teaching can influence preschoolers' motoric and linguistic skills in each class, with students having high and low visual literacy levels. The learning process is divided into two types: WBT dan model group model, which are free variables influencing preschoolers' motoric and language skills.

\section{Data Collection Instruments}

The instruments used in data collection are: (1) Whole brain teaching (WBT) instruments, (2) Visual literacy (VL) instruments (3) Instruments for motor and language 
skills in early childhood. Researchers adapted instruments that had been developed by previous developers. The researcher arranged the instrument through two stages, namely the development stage and the trial phase.

For whole brain teaching (WBT) researchers adapt instruments that have been developed by previous developers, whereas for visual literacy (VL) instruments, instruments for early motor skills and language are developed by researchers themselves who are based on pre-existing indicators. The instrument trials were conducted to obtain valid and reliable instruments in order to guarantee the research data obtained were valid and reliable.

The process of analyzing the validity of items (items) questionnaire whole brain teaching is done by finding the correlation coefficient of the item score with the total score. Item scores are considered as $\mathrm{x}$ values and total scores are considered as y values. To test the correlation of item scores with the total score used Pearson product moment correlation analysis techniques. The results of the calculation of the product moment correlation (rxy) are then consulted with the coefficients in the correlation table (rtable) at a significance level of $5 \%$. The correlation table for $\mathrm{N}=84$ at the $5 \%$ significance level is 0.312 . Instrument items are said to be valid if $r$ count $>r$ table. The calculation of the validity of this whole brain teaching instrument is done with the help of a Microsoft Exel computer program. The results of the trial and validity analysis of the 20 items of the whole brain teaching instrument were declared to be all valid.

Based on calculations with the help of Microsoft Exel's computer program with Cronbach's Alpha technique of 20 items whole brain teaching instrument showed a reliability coefficient of 0.747 . Thus it can be concluded that the whole brain teaching questionnaire has a high level of reliability.

Hypothesis in this study are: (1) there are influences from motoric and linguistic abilities between students using WBT and group model, (2) there is a difference of motoric and linguistic skills of children having visual literacy high and visual literacy low, (3) there is interaction between WBT and visual literacy towards children's motoric and linguistic abilities.

\section{Subject of Research}

This research was targeted to preschoolers aged 5-6 years old at TK Sinar Nyata II and III in Jember East Java, Indonesia. for the 2019-2020 academic year, during the presentation of the theme "DIRIKU (Myself)." The classes as the subject of research were categorized as Table 4 follows.

Table 4

Subject of Research

\begin{tabular}{lll}
\hline \multirow{2}{*}{ Class } & Number of Students & \\
\cline { 2 - 3 } & Sinar Nyata II & Sinar Nyata III \\
\hline B1 (WBT) & 20 & 24 \\
\hline B2 (Group Model) & 20 & 20 \\
\hline
\end{tabular}


There were class B1 with 44 students, and class B2 with 40 students. Then, students from both classes were divided into groups of WBT and group model. The grouping was determined based on the students' motoric and language ability from the results of the early childhood growth test before the 2019-2020 academic year. The students engaged in the test were then ranked based on their scores from the highest to the lowest. Eventually, the highest-scoring students were randomly divided into two groups, and so were the lowest-scoring students, so the researcher found two classes: B1 with 44 students and B2 with 40 students.

\section{FINDINGS}

The data for this research were obtained through experiments on the subject of research to determine the students' motoric and linguistic skills. Before tested using MANOVA, the data of research must fulfill the requirements of the homogeneity assumptions test, Levene's Statistic Test, and covariance similarity test. The results are shown in Table 5 below.

Table 5

Results of Homogeneity Assumptions Test

\begin{tabular}{lll}
\hline Variable & Levene's Statistic & Covariance (Uji Box's M) \\
\hline Motoric & 0,071 & 0.096 \\
Language & 0.094 & 0.096 \\
\hline
\end{tabular}

Referring to Table 5, the results of the homogeneity test revealed the significance value higher than 0.05 , meaning that the variance and covariance of the data groups are similar for both variables. Therefore, the data fulfilled the requirements of the homogeneity test result is 0.998

\section{Influence of Motoric and Linguistic Skills between Students Learning Using WBT and Group Model}

The first hypothesis of this research is that there are influences of motoric and linguistic skills between students learning using WBT and group model. To prove this hypothesis, the test of between-subjects effect was applied with the results shown in table 6 as follows.

Table 6

Results of Test of Between-Subjects Effects

\begin{tabular}{ll}
\hline Variable & Significance \\
\hline Motoric Ability & 0.006 \\
Language Ability & 0.000 \\
\hline
\end{tabular}

Based on Table 6 , it is determined that:

1. The significance value for motoric ability was $0.006<0.05$, meaning that there was significant influence from learning models towards children's motoric skills.

2. The significance value for language ability was $0.000<0.05$, meaning that there was significant influence from learning models towards children's language skills. 
Table 7

Result Multivariate Tests

\begin{tabular}{|c|c|c|c|c|c|c|c|}
\hline Effect & & & Value & $\mathrm{F}$ & Hypothesis df & Error df & Sig. \\
\hline \multirow[t]{4}{*}{ Intercept } & & Pillai's Trace & ,998 & $19465,384^{\mathrm{a}}$ & 2,000 & 79,000 & 000 \\
\hline & & Wilks' Lambda &, 002 & $19465,384^{\mathrm{a}}$ & 2,000 & 79,000 &, 000 \\
\hline & & Hotelling's Trace & 492,795 & $19465,384^{\mathrm{a}}$ & 2,000 & 79,000 &, 000 \\
\hline & & Roy's Largest Root & 492,795 & $19465,384^{\mathrm{a}}$ & 2,000 & 79,000 &, 000 \\
\hline \multirow[t]{4}{*}{ M.PEM } & & Pillai's Trace & 371 & $23,257^{\mathrm{a}}$ & 2,000 & 79,000 &, 000 \\
\hline & & Wilks' Lambda &, 629 & $23,257^{\mathrm{a}}$ & 2,000 & 79,000 &, 000 \\
\hline & & Hotelling's Trace & ,589 & $23,257^{\mathrm{a}}$ & 2,000 & 79,000 &, 000 \\
\hline & & Roy's Largest Root & ,589 & $23,257^{\mathrm{a}}$ & 2,000 & 79,000 &, 000 \\
\hline \multirow[t]{4}{*}{ VL } & & Pillai's Trace &, 155 & $7,221^{\mathrm{a}}$ & 2,000 & 79,000 & ,001 \\
\hline & & Wilks' Lambda & ,845 & $7,221^{\mathrm{a}}$ & 2,000 & 79,000 &, 001 \\
\hline & & Hotelling's Trace &, 183 & $7,221^{\mathrm{a}}$ & 2,000 & 79,000 & ,001 \\
\hline & & Roy's Largest Root &, 183 & $7,221^{\mathrm{a}}$ & 2,000 & 79,000 &, 001 \\
\hline \multirow{4}{*}{$\begin{array}{l}\text { M.PEM } \\
\text { VL }\end{array}$} & * & Pillai's Trace & ,337 & $20,094^{\mathrm{a}}$ & 2,000 & 79,000 &, 000 \\
\hline & & Wilks' Lambda & ,663 & $20,094^{\mathrm{a}}$ & 2,000 & 79,000 &, 000 \\
\hline & & Hotelling's Trace & ,509 & $20,094^{\mathrm{a}}$ & 2,000 & 79,000 &, 000 \\
\hline & & Roy's Largest Root & ,509 & $20,094^{\mathrm{a}}$ & 2,000 & 79,000 &, 000 \\
\hline
\end{tabular}

M.PEM : Learning Model (WBT and Group Model)

VL: Visual Literacy (High and Low)

The difference between Motoric and Language Skills between Students Having Visual Literacy High and Visual Literacy Low

The second hypothesis is that there are differences in motoric and language skills between students having visual literacy high and visual literacy low. To prove this hypothesis, the test of between-subjects effect was applied with the results shown in table 8 as follows.

Table 8

Results of Test of Between-Subjects Effects

\begin{tabular}{ll}
\hline Variable & Significance \\
\hline Motoric Ability & 0,004 \\
Language Ability & 0,000 \\
\hline
\end{tabular}

Based on Table 8, it is determined that:

1. The significance value for motoric ability was $0.004<0.05$, meaning that there were differences in motoric knowledge between students having visual literacy high and visual literacy low.

2. The significance value for language ability was $0.000<0.05$, meaning that there were differences in language ability between students having visual literacy high and visual literacy low.

\section{Interaction between WBT and Visual Literacy towards Childrens' Motoric and Language Skills}

The third hypothesis is that there was an interaction between WBT and visual literacy towards children's motoric and language skills. To prove this hypothesis, the test of between-subjects effect was applied with the results shown in table 9 as follows. 
Table 9

Results of Test of Between-Subjects Effects

\begin{tabular}{ll}
\hline Variable & Significance \\
\hline Motoric Ability & 0,000 \\
Language Ability & 0,000 \\
\hline
\end{tabular}

Based on table 9 , it is determined that:

1. The significance value for motoric ability was $0.000<0.05$, meaning that there was an interaction between WBT and visual literacy towards children's' motoric skills.

The significance value for language ability was $0.000<0.05$, meaning that there was an interaction between WBT and visual literacy towards children's language skills.

\section{DISCUSSION}

The execution of WBT at Sinar Nyata II and III Jember can be described as follows: First, students paid attention to the teacher explaining about WBT, such as (1) class-yes, (2) five classroom rules, (3) teach-ok, (4) the scoreboard, (5) hands and eyes, (6) switch, (7) mirror (Biffle, 2013). The students showed positive response to the new characteristics explained by the teacher; second, the students and the teacher discussed about the themes and subthemes in the lessons; third, the teacher told classroom rules No. 1-5 (Five Class Room) : (1) raise a finger when your name is called out and you are present, (2) raise two fingers if you want to speak, (3) raise three fingers to head out of class, (4) if teacher says Teach, students answer Ok, then discuss with their groups, (5), if teacher says Hand and Eyes during a lesson, students reply hand and eyes by closing both hands and putting them on the table. The teacher began explaining the rules one at a time. The teacher gave an example of movements to help the students memorize the rules. The teacher repeated the explanation of the rules until the students fully memorized and implemented them; fourth, the teacher explained about teach-ok. On this occasion, the teacher related the step to the subtheme teacher and friends. Students were asked to engage in a role-play as teachers by dividing the students into groups of two. The teacher ordered each group to do activities such as discussing, observing, writing, coloring, cutting, attaching. The teacher said "teach" to the students, and the students replied, "ok," followed explaining the lesson to their teammates using gestures; in this group activity, students drew the number 2 . The teacher told the shape of the number 2 using objects and taught how to write number 2 on paper and in the air. All the students listened to the explanation; then, the teacher asked the students to write the number 2 in the air. After all the students understood, the teacher ordered the students to write down the number 2 on paper, as pictured below.
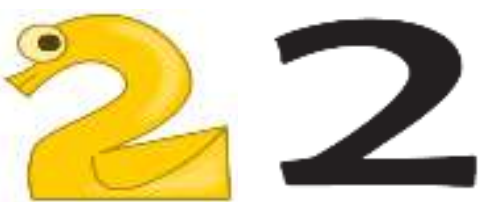

Figure 1

The Shape of the Number '2' Resembling a Duck 
In the fifth step, the teacher said hand and eyes; then, the students replied hand and eyes by closing both hands and putting them on the table. This activity was conducted for the teacher needed to explain the results of learning activities, which is the scoreboard: The teacher gave satisfactory scores (4 smiley faces/stars "satisfactory") if the students well executed the method of whole brain teaching using movements/gesture.

On the other hand, the teacher gave dissatisfactory scores (2 smiley faces/stars "dissatisfactory") if students do not well execute the method of whole brain teaching using movements/gestures. Consequently, in the sixth step called Switch, the teacher has the highest-scoring students' pair with the low and middle scoring students. The seventh and final step was an activity called Mirror, in which the teacher ordered the students to explain the lesson again using movements/gestures, then they taught the lesson to the low and middle scoring teammates. With the implementation of WBT, children's motoric and language ability improves significantly. It is proven from the results of an experiment showing students' behavioral change in learning activities, that is the betterment of children's ability to answer questions proposed by the teachers. The students who once became shy to speak gained more confidence to speak because they got used to the characteristics of WBT. On the other hand, for talkative children, sometimes they did not answer the questions accurately, for they did not understand the teacher's explanations. Since the implementation of WBT, they became more active and able to pay attention to the explanations and gestures from the teacher, so they could answer questions and imitate the movements quickly.

The results of this research showed that there are significant influences from the model of WBT towards children's motoric and linguistic abilities. It is strengthened by many studies, including Marsden (in Biffle, 2013). The research was conducted in California, Arizona, Texas, Montana, Louisiana, Minnesota, Missouri, Florida, Pennsylvania, Arkansas, Tennessee, and Alabama, by surveying 2000 teachers. The results were that $70 \%$ of teachers thought that WBT was better than any other learning model. Learning activities using WBT can be done according to the students' needs (Marzano, Pickering, \& Pollock, 2001). Furthermore, WBT allows students to obtain achievements in learning, because by using this model students become more active in participating in discussions, more optimally applying gestures, being able to follow the class rules, and being able to share new ideas (Biehler \& Snowman, 1986; Snowman, McCowan, \& Biehler, 2009).

\section{CONCLUSION}

The results of this research shows that (1) there are influences of motoric and linguistic skills between students learning using WBT and group model, (2) there are differences of motoric and language skills between students having visual literacy high and visual literacy low, and (3) there is interaction between WBT and visual literacy towards children' motoric and language skills.

\section{IMPLICATIONS}

Based on these results of the theoretical and practical implications can be stated are: theoretical implications: (a) The use of appropriate WBT learning models can affect a 
child's motor skills and language. In the learning process, there is the differences between learning that use of the WBT and group model. (b) Children's visual literacy has an influence on aspects of children's development in learning activities. Children with high visual literacy certainly have better motoric and language skills than children with low visual literacy. It is expected that teachers can grow and develop visual literacy skills in children in various ways according to the ability of teachers and attractive to children. (c) There is an interaction between the WBT learning model and visual literacy in this research, so that the development of motor and language in children develops well. And practical implications is the results of this research are used as input for teachers and prospective teachers in applying the WBT model so that they are able to optimize motor and language skills in preschoolers.

\section{REFERENCES}

Avgerinou, M. D., \& Pettersson, R. (2011). Toward a cohesive theory of visual literacy toward a cohesive theory of visual literacy. Journal of Visual Literacy, 30(2), 1-19. https://doi.org/10.1080/23796529.2011.11674687.

Beaty, J. J. (1998). Observing development of the young child. Prentice Hall.

Biehler, R. F., \& Snowman, J. (1986). Psychology applied to teaching. Boston, USA: Houghton Mifflin.

Biffle, C. (2013). Whole Brain teaching for challenging kids. 04 March. California: Philosophy Department Crafton Hills College Yucaipa.

Burke, A., \& Peterson, S. S. (2007). A multidisciplinary approach to literacy through picture books and drama. English Journal, 96(3), 74. https://doi.org/10.2307/30047299.

Calhoun, C. (2012). Brain-based teaching: Does it really work? Retrieved from https://files.eric.ed.gov/fulltext/ED535937.pdf.

Das, S. W. H. (2018). The character education of early childhood: Brain-based teaching approach, 231(Amca), 25-28. https://doi.org/10.2991/amca-18.2018.8.

Davido, R. D. (1994). The "childhood hand that disturbs" projective test: A diagnostic and therapeutic drawing test. Greenwood Publishing Group.

Davis, J. S. (2011). Games and students: Creating innovative professionals. American Journal of Business Education, 4(1), 1-11.

Duman, B. (2006). The effect of brain-based instruction to improve on students academic achievement in social studies instruction. Paper presented at the $9^{\text {th }}$ International Conference on Engineering Education, San Juan, Puerto Rico.

Edwards, \& Willis, L. M. (2000). Language and literacy development: Integrating visual and verbal literacies in the early childhood classroom. Early Childhood Education Journal, 27(4), 1-20.

Gardner, H. (1993). The theory of multiple intelligences. New York: Basic Books.

Gardner, H. (2011). Frames of mind. New York: Basic Books.

Hajhashemi, K., Caltabiano, N., Anderson, N., \& Tabibzadeh, S. A. (2018). Multiple 
intelligences, motivations and learning experience regarding video-assisted subjects in a rural university. International Journal of Instruction, 11(1), 167-182. https://doi.org/10.12973/iji.2018.11112a.

Hanafiah, Nurapriani, R., \& Gaffar, M. A. (2018). Game model based on cultural values approach in developing interpersonal and kinesthetic intelligences in early childhood. Advances in Social Science, Education and Humanities Research, 249, 1-7. https://doi.org/10.2991/secret-18.2018.1.

Heinich, R., Molenda, M., Russell, J. D., \& Smaldino, S. E. (2002). Instructional media and technologies for learning. New Jersey: Pearson Education, Inc.

Jensen, E. (2008). Brain-based learning: The new paradigm of teaching. Corwin Press.

Kemdikbud. (2019). Data referensi kementerian pendidikan dan kebudayaan.

Kirschner, P. A., Sweller, J., Kirschner, F., \& Zambrano R., J. (2017). From cognitive load theory to collaborative cognitive load theory. Int. Journal of Computer-Supported Collaborative Learning, 13, 213-233. https://doi.org/10.1007/s11412-018-9277-y.

Lenroot, \& Giedd. (2006). Brain development in children and adolescents: Insights from anatomical magnetic resonance imaging. Neuroscience \& Biobehavioral, 30(6), 718729.

Leppo, M. L., Diane, D., \& Crim, B. (2012). The basics of exercising the mind and body. Journal Childhood Education, 76(3), 142-147. https://doi.org/10.1080/00094056.2000.10522095.

Martini Jamaris, E. (2014). Formal multiple intelligences assessment instruments for 4-6 years old children. American Journal of Educational Research, 2(12), 1164-1174. https://doi.org/10.12691/education-2-12-6.

Marzano, R. J., Pickering, D. J., \& Pollock, J. E. (2001). Classroom instruction that works. association for supervision and curriculum development. Alexandria: ASCD.

McMahon, S. D., Rose, D. S., \& Parks, M. (2004). Multiple intelligences and reading achievement: An examination of the teele inventory of multiple intelligences. Journal of Experimental Education, 73(1), 41-52. https://doi.org/10.3200/JEXE.71.1.41-52.

Michelaki, E., \& Bournelli, P. (2016). The Development of bodily - kinesthetic intelligence through creative dance for preschool students. Journal of Educational and Social Research, 6(3), 23-32. https://doi.org/10.5901/jesr.2016.v6n3p23.

Moulson, M. C., Fox, N. A., Zeanah, C. H., \& Nelson, C. A. (2009). Early adverse experiences and the neurobiology of facial emotion processing. Developmental Psychology, 45(1), 17-30.

Palasigue, J. T. (2009). Integrating whole brain teaching strategies to create a more engaged learning environment. A Research Report. Retrieved from http://files.eric.ed.gov/fulltext/ED507407.pdf.

Papalia, D. E., Olds, S. W., \& Feldman, R. D. (2007). Human development. New York: McGraw-Hill. 
Pettersson, R. (2007). Visual literacy in message design. Journal of Visual Literacy, 27(1), 61-90.

Preslee, M., Kharsati, D., \& Prakasha. (2017). Whole brain teaching. IOSR Journal of Humanities and Social Science, 22(6), 76-83. https://doi.org/10.9790/08372206027683

Pretorius, H. W., Steyn, A. A., \& Johnson, R. D. (2012). Pair teaching of ICT in higher education: A multi-perspective reflection. Research in Higher Education Journal, 17(1), 1-12.

Roskos, K. A., \& Christie, J. F. (2017). Play in the context of the new preschool basics. In K. Roskos, \& J. Christie (Eds.), Play and literacy in early childhood (pp. 83-100). Routledge.

Santrock, J. W. (2011). Child development . Dallas: McGraw-Hill Education.

Santrock, J. W. (2018). Educational psychology. Dallas: McGraw-Hill Education.

Silver, E. A., \& Smith, M. S. (1996). Building discourse communities in mathematics classroom: A worthwhile but challenging journey. In P. C. Elliott, \& M. J. Kenney (Eds.), Communication in mathematics. K-12 and benyond: 1996 yearbook (pp.20-28). Reston: VA: NCTM.

Snowman, J., McCowan, R., \& Biehler, R. (2009). Psychology applied to teaching. Boston, USA: Houghton Mifflin Company.

Stearns, P. N. (2017). Childhood in world history. Routledge is an imprint of the Taylor \& Francis Group.

Tufekci, S., \& Demirel, M. (2009). The effect of brain-based learning on achievement, retention, attitude and learning process. Procedia Social and Behavioral Sciences, 1 , 1782-1791.

van Oordt, M. L., van Oordt, T., \& du Toit, P. (2014). Are two teachers better than one? Meditari Accountancy Research, 22(2), 165.

Winona, H., \& Clark, S. (2016a). Effect of whole brain teaching on student selfconcept. Walden University Scholar Works. Retrieved from http://scholarworks.waldenu.edu/dissertations.

Winona, H., \& Clark, S. (2016b). Effect of whole brain teaching on student selfconcept. Walden University Scholar Works. Walden University.

Wohlwend, K. E. (2009). Early adopters: Playing new literacies and pretending new technologies in print-centric classrooms. Journal of Early Childhood Literacy, 9, 117140. https://doi.org/10.1177/1468798409105583.

Wolken, A. S. (2017). Brain-based learning and whole brain teaching methods (Unpublished master thesis). Northwestern Colege, IA.

Wong, A. (2015). Applying whole-brain-teaching in self-financed top-up degrees: An exploratory action research. College of Professional and Continuing Education, 2(6), $1-12$. 